\title{
KESIAPAN PERPUSTAKAAN PERGURUAN TINGGI \\ DALAM MENGHADAPI REVOLUSI INDUSTRI 4.0
}

\author{
MUHAMMAD RUM \\ e_mail: rummuhammad71@gmail.com
}

\section{ILMU PERPUSTAKAAN DAN INFORMASI FAH UIN SULTHAN THAHA SAIFUDDIN JAMBI}

\begin{abstract}
ABSTRAK
Penelitian ini mengkaji secara filosofis menganai kesiapan perpustakaan perguruan tinggi dalam menghadapi industri 4.0. Pembahasan diawali dengan pemaparan singkat mengenai epistimologi, ontologi dan aksiologi. Pembahasan dilanjutkan dengan mengubungkan ilmu filsafat dan ilmu filsafat manajemen sehingga dari kedua disiplin ilmu tersebut ditemukan tiga elemen dasar ilmu manajemen adalah kepemimpinan, manajemen dan adminsitrasi. Terdapat beberapa pandangan ndalan kajian filsafat manajemen terhadap revolusi industri 4.0. Pandangan tersebut yakni penggunaan tekonlogi dapat memberikan efektifitas kerja, sehingga setiap proses pekerjaan dapat diselesaikan dengan baik (smart process). Ilmu filsafat manajemen dalam kaitannya dengan perkembangan revolusi industri 4.0 setidaknya harus menyikapi beberapa hal yakni, inovasi, penurunan biaya produksi marjinal dan munculnya platform yang dapat menyatukan dan mengkonsentrasikan beberapa bidang keilmuan. Ketiga, revolusi secara global ini akan berpengaruh besar dan terbentuk di hampir semua negara di dunia, di mana cakupan transformasi ini terjadi pada setiap bidang industri, dan bahkan akan mempunyai dampak menyeluruh di banyak tempat.
\end{abstract}

Key Word: Filsafat Manajemen, Revolusi Industri 4.0

\section{A. PENDAhULUAN}

Para pakar atau ilmuwan khususnya pakar ilmu manajemen sepakat bahwa perkembangan ilmu pengetahuan yang terjadi di dunia saat ini merupakan sumbangsih dari ilmu filsafat. Salah satu faktor yang mempengaruhi begitu cepatnya perkembangan ilmu pengetahuan dalam berbagai bidang lebih disebabkan doktrin filsafat yang mengajarkan bagaimana menggunakan akal untuk menemukan suatu kebenaran yang dilandasi dengan cara berfikir yang kritis dan sistimatis.

Pengetahuan manusia yang awalnya segelintir ilmu pengetahuan, dengan kemampuan bebrfikir maka lahirlah berbagai jenis ilmu pengetahuan termasuk ilmu manajemen yang merupakan ilmu pengetahuan yang teramat penting. Tentu harus disadari bahwa munculnya berbagai ilmu pengetahuan harus disadari bahwa semua itu merupakan manifestasi untuk kesejahteraan dan kebahagiaan umat manusia sebagai makhluk paripurna.Perkembangan selanjutnya adalah munculnya berbagai perubahan dalam kehidupan umat manusia yang ditandai dengan semakin berperannya teknologi dalam setiap aktivitas 
manusia.Perkembangan teknologi membawa perubahan yang lebih besar yang disebut dengan revolusi industry 4.0 .

Adalah Prof Klaus Schwab, Ekonom terkenal dunia asal Jerman, Pendiri dan Ketua Eksekutif World Economic Forum (WEF) yang mengenalkan konsep Revolusi Industri 4.0. Dalam bukunya yang berjudul "The Fourth Industrial Revolution”, Prof Schawab (2017) menjelaskan revolusi industri 4.0 telah mengubah hidup dan kerja manusia secara fundamental. Berbeda dengan revolusi industri sebelumnya, revolusi industri generasi ke-4 ini memiliki skala, ruang lingkup dan kompleksitas yang lebih luas. Kemajuan teknologi baru yang mengintegrasikan dunia fisik, digital dan biologis telah mempengaruhi semua disiplin ilmu, ekonomi, industri dan pemerintah. Bidang-bidang yang mengalami terobosoan berkat kemajuan teknologi baru diantaranya (1) robot kecerdasan buatan (artificial intelligence robotic), (2) teknologi nano, (3) bioteknologi, dan (4) teknologi komputer kuantum, (5) blockchain (seperti bitcoin), (6) teknologi berbasis internet, dan (7) printer 3D. ${ }^{1}$

\section{B. KAJIAN TEORITIS}

\section{Filsafat ilmu dalam kajian Ontology}

\section{a. Pengertian Ontologi}

Ontologi berasal dari bahasa Yunani yakni ta onta artinya 'yang berada', atau ontos atinya ada atau segala sesuatu yang ada (being), dan logos artinya ilmu pengetahuan atau ajaran. ${ }^{2}$ Dengan demikian ontologi berarti ilmu pengetahuan atau ajaran tentang yang ada

Ontologi adalah cabang teori dari ilmu filsafat yang membicarakan hakikat sesuatu yang ada.Menurut Amsal Bakhtiar bahwa ontologi merupakan azas dalam menerapkan batas atau ruang lingkup wujud yang menjadi obyek penelaahan (obyek ontologis atau obyek formal dari pengetahuan) serta penafsiran tentang hakikat realita (metafisika) dari obyek ontologi atau obyek formal tersebut dan dapat merupakan landasan ilmu yang menanyakan apa yang dikaji oleh pengetahuan dan biasanya berkaitan dengan alam kenyataan dan keberadaan. ${ }^{3}$ Hakikat dari ontology adalah berupaya untuk mencari dan membahas hakikat atau inti dari setiap kenyataan, membicarakan eksistensi dan berbagai

\footnotetext{
${ }^{1}$ Slamet Rosyadi. Revolusi Industri 4.0. Peluang dan Tantangan Bagi Alumni Universitas Terbuka. Fakultas Ilmu Sosial dan Ilmu Politik Universitas Jenderal Soedirman. https://www.google.com/search?safe=strict\&eidiakses tanggal 8 Oktober 2018

${ }^{2}$ Sihol Situngkir. Filsafat Ilmu Dalam Kajian Dimensi Ontologi, Epistimologi dan Aksiologi. (Jambi : Program Doktor Ilmu Ekonomi Kekhususan Ilmu Manajemen Universitas Jambi, 2018), hal. 1

${ }^{3}$ Bakhtiar Amsal. Filsafat Ilmu. (Jakarta : Rajawali Press, 2016), hal. 132
} 
kenyataan.Karena itu ontology bertentangan dengan paham supranaturalisme karena paham ini membahas sesuatu yang tidak konkrit atau nyata.

\section{b. Bidang Kajian Ontologi}

Sebagai cabang ilmu filsafat yang menfokuskan pada hakikat kenyataan, seperti bagaimana adanya wujud yang nyata rumah, satu, ayam dan tidak bersifat.Dengan demikian maka kajian ontology adalah kosmologi dan metafisika dengan segala sumber yang ada yaitu Tuhan sebagai zat Yang Maha Tunggaldan Penguasa Alam Semesta.Studi tentang yang ada umumnya dilakukan oleh filsafat metafisika.

\section{c. Aliran-Aliran dalam Ontologi}

\section{1) Monoisme}

Paham monoisme menganggap bahwa hakikat yang asal dari kenyataan itu hanyalah satu saja sebagai sumber asal baik materi maupun ruhani. ${ }^{4}$ Thomas Davidson menyebutkan monoisme adalah block universe. Paham monoisme terbagi dua aliran yaitu :

a) Materialisme :Menganggap bahwa sumber yang asal adalah materi bukan rohani sering juga naturalisme. Menurut Rapar dalam Praja Juhaya bahwa aliran materialisme menolak hal-hal yang abstrak. Bagi materialisme adayang sesungguhnya adalah yang keberadaannya semata-mata bersifat materialisme, realitas yang sesungguhnya adalah alam kebendaan, sesuatu yang riil atau nyata. ${ }^{5}$ Tokoh-tokoh aliran materialisme adalah Thales, anaximenes dan anaximandris.

b) Idealisme dinamakan juga spritualisme. Idealisme mengandung arti sesuatu yang hadir dalam jiwa. Aliran ini menganggap bahwa hakikat kenyataan yang beranekaragam ini berasal dari ruh yaitu sesuatu yang tidak berbentuk dan menempati ruang. Aliran idealismeini mengalami pertumbuhan dan perkembangan sejak masa Plato yang terkenal dengan focus kajiannya mengenai ide. Ide menurut Plato tidak sama dengandualismeide yang dipahami pada waktu ini. Ide sebagai dasar pijakan pada waktu digambarkan sebagai teori logika selanjutnya meluas menjadi pandangan hidup (way of

\footnotetext{
${ }^{4}$ Oloade O. Shyllon.Monism / Dualism or Self Executory : The Applicaion of Human Rights Treaties Domestic Courts in Africa. Advanced Course on the International Protection of Human Rights.Institute for Human Rights, Abo Akademi University.17 - 28 AUGUST 2009. P. 4

${ }^{5}$ Praja Juhaya S, Aliran-aliran Filsafat dan Etika, (Bandung: Yayasan Piara, 1997).Hal. 152
} 
life) dan kemudian menjadi dasar umum ilmu, ilmu social politik, ilmu agama dan lain-lain..

\section{2) Dualisme}

Aliran dualisme adalah aliran yang berpendapat dengan berusaha untuk menggabungkan dua paham yang saling bertentangan yaitu materialisme dan idealisme. ${ }^{6}$ Aliran dualisme memandang paham yang serba dua yaitu antara materi dan bentuk.Materi dalam arti mutlak adalah asas atau lapisan bawah yang paling akhir dan umum.Tiap benda yang dapat diamati disusun dari materi.Materi dan bentuk tidak dapat dipisahkan.Materi tidak dapat berwujud tanpa bentuk sebaliknya bentuk tidak dapat berada tanpa materi.Tiap benda yang dapat diamati disusun dari bentuk dan materi. ${ }^{7}$

\section{3) Pluralisme}

Paham pluralismemenilai bahwa keaneka ragaman atau segala bentuk perbedaan adalah merupakan kenyataan yang tak dapat dipungkiri.Pluralisme berpijak dari pemikiran bahwa keseluruhan dan harus diakui bahwa segala jenis perbedaan dan misalkan ras, agama dan lain-lain merupakan wujud kongrit yang ada. ${ }^{8}$

\section{4) Nikhilisme}

Dunia ini terbuka untuk kebebasan dan kreativitas manusia.Dalam paham ini manusia bebas berkehendak dan berkreativitas. ${ }^{9}$

\section{5) Agnotisisme}

Aliran ini menganut paham bahwa manusia tidak mungkin mengetahui hakikat sesuatu dibalik kenyataannya. Manusia tidak mungkin memiliki hakekat batu, air, dan api. Kemampuan manusia sangat terbatas dan tidak mungkin tahu hakikat sesuatu yang ada.Paham agnotisisme mengingkari kesanggupan manusia untuk mengetahui hakikat benda baik materi maupun hakikat rohani. ${ }^{10}$

\footnotetext{
${ }^{6}$ George Stuart Fullerton. An Introduction to Philosophy.(New York: MacMillan, 1915). P.

${ }^{7}$ Ibid. Oloade O. Shyllon.Monism / Dualism...... p. 6

${ }^{8}$ IbidOloade O. Shyllon.Monism / Dualism ...... p.6

${ }^{9}$ IbidOloade O. Shyllon.Monism / Dualism ...... p. 6

${ }^{10}$ IbidOloade O. Shyllon.Monism / Dualism ...... p.6
} 


\section{Epistimologi}

\section{a. Pengertian Epistimologi}

Epistemologi adalah suatu cabang filsafat yang mengkaji tentang usaha dan upaya untuk mencari tahu suatu kebenaran secara hakiki. ${ }^{11}$ Batasan dari epistemologi merupakan adalah batasan dari pola pikir manusia, sehingga kebenaran sejati yang tidak dapat dicapai oleh manusia adalah milik tuhan semata.Dagobert D' Runes, seorang ahli filsafat dari Universitas Vienna menyatakan bahwa Hakikat dari Epistemologi merupakan upaya dalam mekaji sumber dari kebenaran atau ilmu secara structural. ${ }^{12}$ Masalah utama yang dihadapi dari kajian Epistemologi secara menyeluruh pada ilmu sains adalah bagaimana cara mengetahui pengetahuan secara hakiki

\section{b. Hubungan antara Epistemologi, Metode dan Metodologi}

Peter R. Senn, Guru besar dari Wright College, menekankan bahwa prosedur merupakan sebuah cara untuk mencari tahu secara sistematis dan prosedur sedangkan metodologi merupakan sebuah pengkajian yang mendalam tentang prosedur-prosedur yang ada pada metode tersebut. Kata logos dari metodologi merepresentasikan ilmu yang membahas tentang metoda.Metodologi merupakan sebuah disiplin yang mengkaji metode secara konseptual mengenai permasalahan yang didapatkan pada saat melakasanakan prosedurprosedur.Sebagai cabang ilmu yang mempelajari metode, Metodologi merupakan kajian teoritik tentang berbagai metode.Kajian teoritik ini selanjutnya membahas mengenai kelebihan dan kelemahan dalam karya ilmiah.

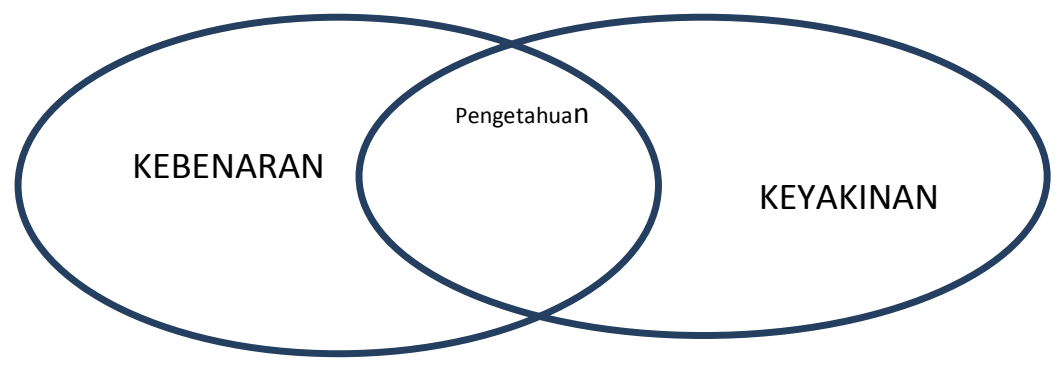

${ }^{11}$ Ibid. Sihol Situngkir. Filsafat Ilmu Dalam Kajian.....hal. 3, lihat juga pembahasan etismologi yang dikemukakan oleh Alan Doldman dalam buku Fundamentals of Philosoophy (London : Routledge, 2004), p. 11 bahwa filsafat asal muasalnya berkaitan dengan alam, lingkup dan struktur pengetahuan. Epistimologi mengenai apa yang dikaji oleh pengetahuan itu, menganalisis, dan memandu untuk memahami lingkup pengetahuan, bagaimana pengetahuan yang kita miliki. Epistimologi berusaha menjawab tantangan-tantangan skeptis mengenai sumber-sumber yang diasumsikan untuk menghasilkan pengetahuan, misalnya persepsi, memori, testimony dan berbagai jenis-jenis lainnya

${ }^{12}$ Raymond Bradley / Norman Swartz. Possible Words :A Introduction to logic and its philosophy. ( USA : Hackett Pbulishing Company, 1988), p. 


\section{Aksiologi}

Aksiologi berasal dari kata axios (nilai) dan logos (teori).Aksiologi disebut juga sebagai teori nilai. Pendekatan aksiologi menilai apakah sesuatu itu baik atau buruk, benar atau salah serta tentang cara dan tujuan.

Dalam Encyclopedia of Philosophy dijelaskan bahwa aksiologi disamakan dengan value dan valuation. Ada tiga bentuk value dan valuation, yaitu: 1) Nilai, sebagai suatu kata benda abstrak; 2) Nilai sebagai kata benda konkret; 3) Nilai juga digunakan sebagai kata kerja dalam ekspresi menilai. Nilai-nilai yang juga harus melekat pada ilmuan, sebagaimana juga dicirikan sebagai manusia modern: (1) Nilai teori: manusia modern dalam kaitannya dengan nilai teori dicirikan oleh cara berpikir rasional, orientasinya pada ilmu dan teknologi, serta terbuka terhadap ide-ide dan pengalaman baru. (2) Nilai sosial : dalam kaitannya dengan nilai sosial, manusia modem dicirikan oleh sikap individualistik, menghargai profesionalisasi, menghargai prestasi, bersikap positif terhadap keluarga kecil, dan menghargai hak-hak asasi perempuan; (3) nilai ekonomi : dalam kaitannya dengan nilai ekonomi, manusia modem dicirikan oleh tingkat produktivitas yang tinggi, efisien menghargai waktu, terorganisasikan dalam kehidupannya, dan penuh perhitungan; (4) Nilai pengambilan keputusan: manusia modern dalam kaitannya dengan nilai ini dicirikan oleh sikap demokratis dalam kehidupannya bermasyarakat, dan keputusan yang diambil berdasarkan pada pertimbangan pribadi; (5) Nilai agama: dalam hubungannya dengan nilai agama, manusia modem dicirikan oleh sikapnya yang tidak fatalistik, analitis sebagai lawan dari legalitas, penalaran sebagai lawan dari sikap mistis. ${ }^{13}$

Aksiologi menjadi dasar untuk berprilaku etis atau moral.Ada dua yang menjadi fokus dalam kajian ontology yang cukup mewarnai dalam perkembangan ilmu pengetahuan adalah objektivisme dan subjektivisme.Kedua-duanya mempertanyakan apakah nilai itu bergantung atau tidak, bergantung pada manusia.Oleh karena itu dikenal empat pendekatan etis yaitu teori intutitif, teori nilai rasional, teori nilai alamiah, dan teori nilai emotif. ${ }^{14}$

\footnotetext{
${ }^{13}$ Susanto A, Filsafat Ilmu, Suatu Kajian dalam Dimensi Ontologis, Epistimologis,dan Aksiologis, (Jakarta: Bumi Aksara, 2011), hal. 121

${ }^{14}$ Will Durrant. The Story f Philosophy. (New York : Garden City Publishing, 1986), p. 87
} 


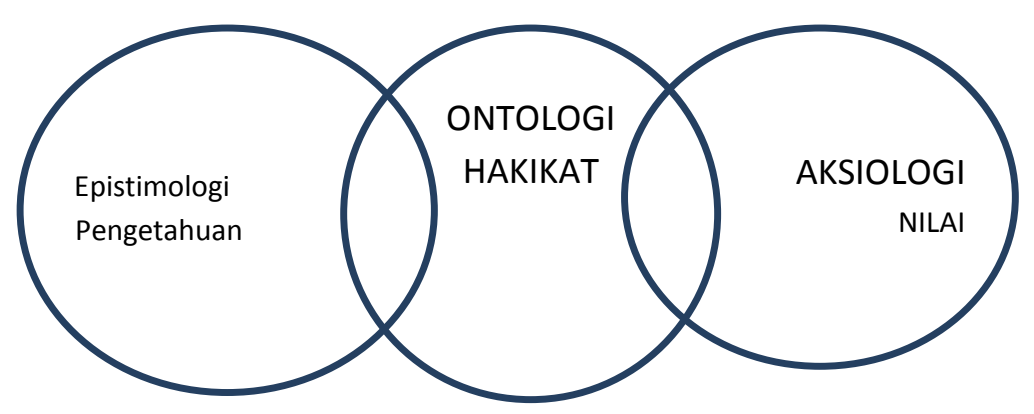

Berdasarkan gambar di atas menunjukkan adanya perbedaan antara ontology, epistimologi dan aksiologi. Masing-masing memiliki kajian dan pembahasan tersendiri yang berlandaskan dari filsafat.

Tabel 1. Perbedaan antara epistimologi, ontology dan aksiologi

\begin{tabular}{|l|l|l|ll|}
\hline & Epistimologi & Ontologi & Aksiologi & \\
\hline Pengetahuan & $\begin{array}{l}\text { Membahas } \\
\text { bagaimana cara } \\
\text { mendapatkan } \\
\text { pengetahuan }\end{array}$ & $\begin{array}{l}\text { Apa yang ingin } \\
\text { diketahui }\end{array}$ & $\begin{array}{l}\text { Membahas nilai } \\
\text { kegunaan } \\
\text { pengetahuan }\end{array}$ \\
\hline Teori & $\begin{array}{l}\text { Mempelajari teori } \\
\text { tentang } \\
\text { pengetahuan }\end{array}$ & $\begin{array}{l}\text { Mempelajari yang } \\
\text { ada }\end{array}$ & $\begin{array}{l}\text { Mempelajari teori } \\
\text { tentang nilai }\end{array}$ \\
\hline
\end{tabular}

\section{Perkembangan ilmu filsafat dan filsafat ilmu manajemen}

Sebagaimana yang sudah lazim kita ketahui bahwa munculnya ilmu pengetahuan adalah dilatarbelakangi bagaimana peran filsafat, dan munculnya ilmu pengetahaun adalah untuk memperkuat keberadaan filsafat. Filsafat ilmu pengetahuan merupakan cabang filsafat yang membahas tentang sejarah perkembangan ilmu pengetahuan, pengetahuan, metode-metode ilmiah, serta sikap etis yang harus dikembangkan oleh para ilmuwan, yang berfungsi sebagai sarana pengujian penalaran sains, merefleksi, menguji, mengkritik asumsi dan metode keilmuan; serta memberikan landasan logis terhadap metode keilmuan. ${ }^{15}$ Ilmu manajemen misalnya sebagai salah satu cabang ilmu pengetauan dimana kolektivitas orang-orang yang melakukan aktivitas manajemen karena didasarkan pada metode berfikir untuk menyelesaikan persoalan-persoalan dalam tata kelola organisasi. Landasan filosofis munculnya ilmu ini adalah berangkat dari beberapa pertanyaan antara lain mengenai hakikat sains empirikal, seperti obyek apa yang ditelaah ilmu manajemen? Bagaimana wujud yang hakiki dari obyek ilmu manajemen tersebut? Bagaimana hubungan antara obyek tersebut dengan daya tangkap manusia (seperti berpikir, merasa, dan

${ }^{15}$ Ibid. Susanto A, Filsafat Ilmu, ... hal. 108 
mengindera) yang membuahkan pengetahuan? Pertanyaan-pertanyaan ini disebut landasan ontologism. Kemudian muncul pertanyaan lain mengenai bagaimana proses yang memungkinkan diperolehnya pengetahuan yang berupa ilmu? Bagaimana prosedurnya? Hal-hal apa yang harus diperhatikan agar kita mendapatkan pengetahuan yang benar? Apa yang disebut kebenaran itu? Apa kriterianya? Cara/teknik/sarana apa yang membantu kita dalam mendapatkan pengetahuan yang berupa ilmu? Pertanyaan-pertanyaan ini disebut landasan epistemologis. Pertanyaan terakhir adalah untuk apa pengetahuan yang berupa ilmu itu dipergunakan? Bagaimana kaitan antara cara penggunaan tersebut dengan kaidah-kaidah moral? Bagaimana penentuan obyek yang ditelaah berdasarkan pilihan-pilihan moral? Bagaimana kaitan antara teknik prosedural yang merupakan operasionalisasi metode ilmiah dengan norma-norma moral/profesional? Pertanyaan-pertanyaan ini adalah landasan aksiologis.

Salah satu sumbangsih dari ilmu filsafat adalah berusaha untuk mencari kebenaran melalui proses berfikir yang sistimatis. Proses tersebut secara sistimatis menemukan, menyeleksi, mengorganisasi, menciptakan, memperbarui, menyajikan dan menerapkannya. Proses tersebut mempunyai empat tahap yang membentuk siklus yaitu tahap kesadaran internal (internal awareness), respon internal (internal responsiveness), respon eksternal (external responsiveness), dan kesadaran eksternal (external awareness). Siklus inilah pada akhirnya melahirkan pengetahuan manajemen.

\section{Kerangka Filosofis dalam Praktik Ilmu Manajemen}

Ada tiga elemen yang paling mendasar dalam praktik ilmu manajemen adalah kepemimpinan, manajemen dan adminsitrasi ${ }^{16}$. Pemaknaan secara filosofis dari ketiga elemen tersebut antara lain; pertama, kepemimpinan seorang pemimpin (manajer) adalah seorang pemimpin secara kelembagaan harus memiliki kemampuan dalam mengelola lembaga atau organisasi yang dipimpinnya, kemampuan dalam memimpin ini menghasilkan nilai yang mampu mengatasi segala persoalan yang sering mengemuka di lingkungan organisasi. Kemampuan dalam mengatasi ini berangkat dari suatu pemahaman terhadap ilmu.Pemahaman keilmuan yang tepat bagi seorang manajer akan memberikan kemampuan berpikir rasional kognitif dalam pencapaian tujuan organisasi dan kemampuan berpikir rasional komunikatif dalam menangani

\footnotetext{
${ }^{16}$ Sihol Situngkir. Selayang Pandang Tentang Filsafat Ilmu Manajemen (paper) Filsafa Ilmu pada Program Doktor Ilmu Ekonomi kekhususuan Manajemen Sumber Daya Manusia Universitas Jambi.Hal. 7
} 
masalah-masalah normatif. ${ }^{17}$ Kedua, manajemen adalah ilmu yang mempelajari mengenai tata kelola suatu organisasi atau lembaga yang mengandung nilai estetika yang merupakan bagian dari kajian ontologis. Ketiga, administrasi merupakan

\section{PEMBAHASAN}

\section{Pandangan Filsafat Manajemen Terhadap Revolusi Industry 4.0}

Revolusi industry 4.0 adalah Revolusi industri generasi keempat yang ditandai dengan kemunculan superkomputer, robot pintar, kendaraan tanpa pengemudi, editing genetik dan perkembangan neuroteknologi yang memungkinkan manusia untuk lebih mengoptimalkan fungsi otak.

Filsafat manajemen yang mengacu pada kajian ontology yang mengandung bahwa teori tentang nilai yang diinginkan atau teori tentang nilai yang baik dan dipilih. Berdasarkan hal tersebut maka nilai memiliki makna (1) sifat nilai, (2) tipe nilai, (3) kriteria nilai, dan (4) status metafisika nilai. Sifat nilai atau paras nilai didukung oleh pengertian tentang pemenuhan hasrat, kesenangan, kepuasan, minat, kemauan rasional yang murni, serta persepsi mental yang erat sebagai pertalian antara sesuatu sebagai sarana untuk menuju ke titik akhir atau menuju kepada tercapainya hasil yang sebenarnya. Di dalam mengkaji Manajemen berkecimpung tentunya dilandasi dengan hasrat untuk mendapatkan kepuasan. Perihal tipe nilai didapat informasi bahwa ada nilai intrinsik dan ada nilai instrumental. Nilai intrinsik ialah nilai konsumatoris atau yang melekat pada diri sesuatu sebagai bobot martabat diri (prized for their own sake). Yang tergolong ke dalam nilai intrinsik adalah kebaikan dari segi moral, kecantikan, keindahan, dan kemurnian.Nilai instrumental adalah nilai penunjang yang menyebabkan sesuatu memiliki nilai intrinsik. ${ }^{18}$

Dengan demikian bahwa filsafat manajemen menilai bahwa perkembangan revolusi industry 4.0 dalam praktik ilmu manajemen sesungguhnya memberikan nilai dua sisi yaitu nilai positif dan negative. Seperti pada kasus EE Times University yang dikembangkan oleh Pablo Valerio berupa smart phone dimana aplikasi ini mampu memberikan efektifitas kerja karena memungkinkan setiap individu mampu menyelesaikan pekerjaan dengan saling berhadapan (interface) tanpa batas. Menurut beliau era ini ditandai dengan sebuah fase yang secara umum tentang otomatisasi dan pertukaran data dalam teknologi pabrik, robotic dan artificial intellegence. Fase yang

\footnotetext{
${ }^{17}$ John Dixon, Rhys Dogan, and Alan Sanderson .The situational Logic of Social Action. (Hauppauge (USA), Nova Science Publisher, 2012). P.

${ }^{18}$ Ibid. Susanto A, Filsafat Ilmu, ... hal. 121
} 
pada akhirnya menghasilkan "Smart Process". Di dalam Smart Process tersusun moduler, algoritma, sistem siber-fisik mengawasi proses fisik, menciptakan salinan dunia fisik secara virtual, dan membuat keputusan secara desentralisasi.

\section{Nilai-Nilai Dalam Perkembangan Revolusi Industri 4.0}

Ada beberapa nilai positif yang diambil dari revolusi industry 4.0, antara lain: pertama, terwujudnya tata kelola lembaga atau organisasi yang efektif dan efisien karena didukung dengan industry teknologi informasi yang mumpuni. Kedua, hasil kegiatan produktifitas yang didukung dengan manajemen teknologi informasi yang memungkinkan terdistribusi dengan cepat berimpak pada kesejahteraan manusia. Hakikat dari sifat nilai yang mencakup hasrat, kesenangan, kepuasan, minat, kemauan rasional adalah sebagai gambaran dari proses berfikir manusia untuk menemukan sesuatu yang dapat memberikan kebahagiaan bagi umat manusia. Ketiga, untuk mengurangi segala kemungkinan resiko dalam setiap kegiatan manajemen sebab berdampak pada kehidupan manusia. Patrick Mannion seorang konsultan menyebutkan bahwa industry 4.0 sangat membantu masyarakat menginformasikan dan mendesian kemungkinan resiko melalui sistim teknologi on-line. ${ }^{19}$

Sisi negatif, pertama, memungkinkan munculnya gap dan keserakahan umat manusia sebagai wujud dari kecanggihan teknologi informasi. Hasrat manusia yang selalu ingin mencapai kepuasan akan memberikan ruang untuk menguasai atau memonopoli orang lain. Kedua, secara kultur akan berdampak pada hubungan harmonis umat manusia yang sudah terbangun, dengan kehadiran berbagai teknologi khususnya pada teknologi informasi akan memberikan ruang kepada setiap individu untuk tidak saling mengenal secara fisik. Ketiga, Potensi meningkatnya jumlah pengangguran, masalah -- masalah sosial akibat pemutusan hubungan kerja dan masih banyak potensi dampak lainnya.

Berdasarkan uraian di atas, setidaknya ada tiga hal yang dapat disikapi dari perkembangan revolusi industry 4.0 dari perspektif filsafat manajemen.Tiga hal tersebut menjadi alasan mengapa transformasi yang terjadi saat ini bukan merupakan suatu perpanjangan revolusi digital, namun lebih merupakan suatu revolusi transformasi baru. Pertama, inovasi dapat dikembangkan dan menyebar jauh lebih cepat dari sebelumnya.Kecepatan terjadinya terobosan-terobosan baru pada era ini

\footnotetext{
${ }^{19}$ Pablo Valerio. EE Times University.Materi Filsafat Ilmu pada Program Doktor Ilmu EKonomi Kekhususan Ilmu Manajemen Universitas Jambi tahun 2018.Hal. 13
} 
terjadi pada skala eksponensial dan bukan lagi pada skala linear. Kedua, penurunan biaya produksi marjinal dan munculnya platform yang dapat menyatukan dan mengkonsentrasikan beberapa bidang keilmuan terbukti meningkatkan output pekerjaan. Transformasi ini mengakibatkan perubahan dengan ruang lingkup yang begitu luas sehingga menyebabkan perubahan pada seluruh sistem produksi, manajemen, maupun tata kelola. Ketiga, revolusi secara global ini akan berpengaruh besar dan terbentuk di hampir semua negara di dunia, di mana cakupan transformasi ini terjadi pada setiap bidang industri, dan bahkan akan mempunyai dampak menyeluruh pada level sistem di banyak tempat.

\section{KESIMPULAN}

Berdasarkan deskripsi diatas menunjukkan bahwa Ada beberapa nilai positif yang diambil dari revolusi industry 4.0, antara lain: pertama, terwujudnya tata kelola lembaga atau organisasi yang efektif dan efisien. Kedua, hasil kegiatan produktifitas yang didukung dengan manajemen teknologi informasi yang memungkinkan terdistribusi dengan cepat berdampak pada kesejahteraan manusia. Ketiga, untuk mengurangi segala kemungkinan resiko dalam setiap kegiatan manajemen sebab berdampak pada kehidupan manusia.

Sisi negatif, pertama, memungkinkan munculnya gap dan keserakahan umat manusia sebagai wujud dari kecanggihan teknologi informasi. Hasrat manusia yang selalu ingin mencapai kepuasan akan memberikan ruang untuk menguasai atau memonopoli orang lain. Kedua, secara kultur akan berdampak pada hubungan harmonis umat manusia yang sudah terbangun. Ketiga, potensi meningkatnya jumlah pengangguran, masalah -- masalah sosial akibat pemutusan hubungan kerja dan masih banyak potensi dampak lainnya.

Berdasarkan uraian di atas, setidaknya ada tiga hal yang dapat disikapi dari perkembangan revolusi industry 4.0 dari perspektif filsafat manajemen. Tiga hal tersebut menjadi alasan mengapa transformasi yang terjadi saat ini bukan merupakan suatu perpanjangan revolusi digital, namun lebih merupakan suatu revolusi transformasi baru. Pertama, inovasi dapat dikembangkan dan menyebar jauh lebih cepat dari sebelumnya. Kedua, penurunan biaya produksi marjinal dan munculnya platform. Transformasi Ketiga, revolusi secara global ini akan berpengaruh besar dan terbentuk di hampir semua negara di dunia, di mana cakupan transformasi ini terjadi pada setiap bidang industri, dan bahkan akan mempunyai dampak menyeluruh pada level sistem di banyak tempat. 


\section{DAFTAR PUSTAKA}

Slamet Rosyadi. Revolusi Industri 4.0. Peluang dan Tantangan Bagi Alumni Universitas Terbuka.Fakultas Ilmu Sosial dan Ilmu Politik Universitas Jenderal Soedirman. https://www.google.com/search?safe=strict\&eidiakses tanggal 8 Oktober 2018

Sihol Situngkir. Filsafat Ilmu Dalam Kajian Dimensi Ontologi, Epistimologi dan Aksiologi. (Jambi : Program Doktor Ilmu Ekonomi Kekhususan Ilmu Manajemen Universitas Jambi, 2018)

Bakhtiar Amsal. Filsafat Ilmu. (Jakarta : Rajawali Press, 2016)

Oloade O. Shyllon. Monism / Dualism or Self Executory : The Applicaion of Human Rights Treaties Domestic Courts in Africa. Advanced Course on the International Protection of Human Rights. Institute for Human Rights, Abo Akademi University.17 - 28 AUGUST 2009.

Praja Juhaya S, Aliran-aliran Filsafat dan Etika, (Bandung: Yayasan Piara, 1997).

George Stuart Fullerton. An Introduction to Philosophy.(New York: MacMillan, 1915).

Alan Doldman dalam buku Fundamentals of Philosoophy (London : Routledge, 2004), Raymond Bradley / Norman Swartz. Possible Words :A Introduction to logic and its philosophy. ( USA : Hackett Pbulishing Company, 1988)

Susanto A, Filsafat Ilmu, Suatu Kajian dalam Dimensi Ontologis, Epistimologis, dan Aksiologis, (Jakarta: Bumi Aksara, 2011)

Will Durrant. The Story f Philosophy. (New York : Garden City Publishing, 1986)

Sihol Situngkir. Selayang Pandang Tentang Filsafat Ilmu Manajemen (paper) Filsafa Ilmu pada Program Doktor Ilmu Ekonomi kekhususuan Manajemen Sumber Daya Manusia Universitas Jambi.

John Dixon, Rhys Dogan, and Alan Sanderson .The situational Logic of Social Action. (Hauppauge (USA), Nova Science Publisher, 2012)

Pablo Valerio. EE Times University.Materi Filsafat Ilmu pada Program Doktor Ilmu EKonomi Kekhususan Ilmu Manajemen Universitas Jambi tahun 2018. 